\title{
Amylase Production from Solid State Fermentation and Submerged Liquid Fermentation by Aspergillus niger
}

\author{
G. Dharani ${ }^{\mathrm{a}}$ and N. S. Kumaran*b \\ ${ }^{a}$ Kurinji College of Arts and Sciences, Department of Microbiology, Thiruchirapalli, Tamil Nadu, India and \\ ${ }^{b}$ Centre of Advanced Study in Marine Biology, Faculty of Marine Sciences, Annamalai University, Parangipettai \\ - 608 502, Tamil Nadu, India.
}

\begin{abstract}
The purpose of this work is to study the optimized cultural conditions for the production of amylase by Aspergillus niger in solid state and submerged liquid fermentation. Four solid substrates banana peel, corn, potato and tapioca with different moisture conditions were taken for solid state fermentation (SSF). Basal medium was used for submerged liquid fermentation (SLF) with different $\mathrm{pH}$ (3 to 8 ), temperature $\left(25,30,35\right.$ and $\left.40^{\circ} \mathrm{C}\right)$, carbon concentration $(1,2$ and $3 \mathrm{~g})$ and nitrogen source $(0.1,0.2$ and $0.3 \mathrm{~g})$. In SSF, tapioca yielded highest amylase activity and specific activity $(4.43 \mathrm{U} / \mathrm{ml}$ and $4.58 \mathrm{U} / \mathrm{mg})$ at $50 \%$ moisture content. In SLF, $2 \mathrm{~g}$ starch and $0.3 \mathrm{~g}$ peptone concentration showed 0.78 and $1.23 \mathrm{U} / \mathrm{ml}$ amylase activities under the optimum $\mathrm{pH}(5)$ and temperature $\left(30^{\circ} \mathrm{C}\right)$ the amylase activities reached to $0.86 \mathrm{U} / \mathrm{ml}$ and $0.76 \mathrm{U} / \mathrm{ml}$ respectively. In SSF using tapioca as substrate the enzyme yield is about five times higher than that achieved with submerged liquid culture.
\end{abstract}

Key words: Tapioca, Solid state fermentation, Submerged liquid fermentation, $\mathrm{pH}$, Temperature, Amylase activity

\section{Introduction}

Microorganisms made significant contribution for the production of foods and beverages in the past three centuries. Various industries, such as food, brewing, textile, pharmaceutical and confectionaries depends mainly on various products especially extracellular enzymes. In recent years, using of microorganisms as biotechnological sources as industrially relevant enzymes, have stimulated renewed interest in the exploration of extracellular enzymatic activity in several microorganisms (Ibukun and Adindumila, 1998).

Enzymes are the most important products, obtained through microbial sources for human needs. Among these biomolecules, amylase an exo-acting enzyme that yields maltose on hydrolysis of various starches. The $\alpha$-amylase is being isolated from a number of microbial sources and every enzyme moiety isolated from various microbial sources is unique in their characteristics. Various attempts have been made so far on studying the yield and potential of $\alpha$-amylase from different microbial strains. Fungal and bacterial amylases are widely used for commercial application in food processing industries (Burhan et al., 2003). The Aspergillus species produce a variety of extracellular enzymes of which amylases are of the world-wide interest in fermentation, food, pharma- ceutical, textile and paper industries (Rao and Satyanarayana, 2007; Bhargav et al., 2008).

Production of amylases by Aspergillus strains in both submerged liquid fermentation (SLF) and solid-state fermentation (SSF) by using different food wastes or agricultural residues has been thoroughly studied (Ellaiah et al., 2002; Francis et al., 2002, 2003; Salas et al., 2006). However, comparative studies between SLF and SSF claim higher yields and other advantages for products obtained by SSF, such as low energy requirements, lower availability of water that reduces the possibilities of contamination by bacteria and yeast, small volumes of polluting effluents and low downstream processing cost (Guerra et al., 2003). The production of amylases in SSF is affected by a variety of physicochemical factors, including the type, nutrient composition of the substrate, incubation temperature, $\mathrm{pH}$, aeration, concentration and the type of carbon, phosphate and nitrogen sources, concentration and age of the inoculum, particle size and moisture level of the substrate (Balkan and Ertan, 2007; Rodriguez and Sanroman, 2006). Therefore, after selecting a culture medium for amylase production, the fermentation

*Corresponding author. E-mail: s. kumaran08@gmail.com 
conditions must be optimized to improve enzyme production at a low production cost (Balkan and Ertan, 2007; Spier et al., 2006). The purpose of this work was to study the production of the enzyme, amylase by Aspergillus niger in solid state and submerged liquid cultures and optimized the cultural conditions such like appropriate substrate, $\mathrm{pH}$, temperature, moisture level, total sugars concentrations, concentrations of nitrogen sources.

\section{Materials and Methods}

\section{Microorganism}

Aspergillus niger was isolated from infected potato and maintained in potato dextrose agar (PDA) (Hi-media, Mumbai). Isolated colonies were identified based on the morphological characters by fungal staining procedure and it was maintained on potato dextrose agar slants at $4^{\circ} \mathrm{C}$ (Ellaiah et al., 2002; Salas et al., 2006).

\section{Inoculum}

The inoculum was prepared by the addition of sterile distilled water into the freshly grown potato dextrose agar slants, from this $0.5 \mathrm{ml}$ of cell suspension was inoculated in to $50 \mathrm{ml}$ ( $250 \mathrm{ml}$ Erlenmeyer flasks) of sterilized fermentation medium and incubated at $35^{\circ} \mathrm{C}$ and $220 \mathrm{rpm} / \mathrm{min}$ for 48 hrs (Salas et al., 2006). The composition of the fermentation medium $\left(\mathrm{gl}^{-1}\right)$ : glucose, 20 ; $\left(\mathrm{NH}_{4}\right)_{2} \mathrm{SO}_{4}, 6.6 ; \mathrm{KH}_{2} \mathrm{PO}_{4}, 3.5$; $\mathrm{FeSO}_{4} \cdot 7 \mathrm{H}_{2} \mathrm{O}, 0.15 ; \mathrm{MgSO}_{4} .7 \mathrm{H}_{2} \mathrm{O}, 0.10 ; \mathrm{MnCl}_{2} .2 \mathrm{H}_{2} \mathrm{O}, 0.45$ and mycological peptone, 3.0; at pH 6.8.

\section{Fermentation Mediums}

\section{Solid substrates}

Banana peel, corn, potato and tapioca were cut into small pieces and air dried at $40^{\circ} \mathrm{C}$. The substrates were moistured with water to adjusted water content of $40 \%, 50 \%$, and $60 \%$ in conical flasks

\section{Liquid mediums}

The fungus was grown in basal medium. Liquid state fermentation was carried at varying $\mathrm{pH}$ (3 to 8), temperature $\left(25,30,35\right.$ and $\left.40^{\circ} \mathrm{C}\right)$ concentration of the carbon source $(1$ $\mathrm{g}, 2 \mathrm{~g}$ and $3 \mathrm{~g})$, and concentration of the nitrogen source $(0.1$ $\mathrm{g}, 0.2 \mathrm{~g}$, and $0.3 \mathrm{~g}$ ).

\section{Inoculation of samples}

\section{Solid state fermentation}

The solid media were sterilized in $250 \mathrm{~mL}$ conical flask along with sterile water. To the Aspergillus niger slant tube, sterile water was added and scratched with inoculation loop to obtain a spore suspension. Each conical flask was inoculated with $1 \mathrm{ml}$ of fungal suspensions and was incubated in rotatory shaker at $200 \mathrm{rpm}$ for $48 \mathrm{~h}$.

\section{Liquid state fermentation}

Liquid media were sterilized in and then each conical flask, inoculated with $1 \mathrm{~mL}$ of liquid suspension of Aspergillus niger and then incubated in rotatory shaker at $200 \mathrm{rpm}$ for $48 \mathrm{~h}$.

\section{Extraction of the enzyme}

After fermentation, the fermented slurry was mixed with water to $100 \mathrm{ml}$. Contents were mixed thoroughly (150 $\mathrm{rpm} / \mathrm{min}$, at room temperature for $1 \mathrm{~h}$ ) in a rotary shaker and the suspension was then centrifuged at $7000 \mathrm{rpm}$ at $4^{\circ} \mathrm{C}$ for $10 \mathrm{~min}$ and the supernatants were used for enzyme assay.

\section{Analytical method}

\section{Amylase assay}

Amylase activity was determined as described by Okolo et al. (1995). The reaction mixture consisted of $1.25 \mathrm{~mL}$ of $1 \%$

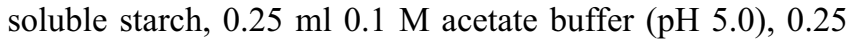
$\mathrm{ml}$ of distilled water, and $0.25 \mathrm{~mL}$ of crude enzyme extract. After $10 \mathrm{~min}$ of incubation at $50^{\circ} \mathrm{C}$, the liberated reducing sugars (glucose equivalents) were estimated by the dinitrosalicylic acid (DNS) method of Miller (1959). The colour developed was read at $575 \mathrm{~nm}$ using a Hitachi 220s UV spectrophotometer. Glucose was used as the standard. The blank contained $0.5 \mathrm{~mL}$ of $0.1 \mathrm{M}$ acetate buffer ( $\mathrm{pH} 5.0$ ), 1.25 $\mathrm{ml} 1 \%$ starch solution and $0.25 \mathrm{~mL}$ distilled water. One unit (IU) of $\alpha$-amylase was defined as the amount of enzyme, releasing one $\mu \mathrm{mol}$ glucose equivalent per minute under the assay rendition.

\section{Estimation of soluble protein}

Soluble protein concentrations were determined in the aqueous extract of fermented matters were determined by the method of Lowry et al. (1951) using bovine serum albumin as standard. 


\section{Results and Discussion}

In recent years, application of the agro industrial residues (i.e., sugar cane bagasse, sugar beet pulp, apple pomace, wheat bran) provided an alternate way to replace the pure and costly raw materials. In industrial process the use of such materials would help to solve many environmental hazards (John et al., 2006). Extensive works are going on all over the world to select the suitable organisms and efficient inducers for the production of concentrated $\alpha$-amylases using biomass wastes in solid-state fermentation. The selection of a suitable solid substrate in solid state fermentation (SSF) is a critical factor. In literature different solid substrates were found to influence the production of enzymes (Beckord et al., 1945; Satyanarayana,1994). Hamilton et al. (1999) reported that the growth and enzyme production by microorganisms were greatly influenced by both environmental conditions and nutrients available within the growth medium. The critical importance of moisture level in SSF media, its influence on the biosynthesis and selection of enzymes can be attributed to the interference of moisture in the physical properties of the solid particles. An increase in moisture level is believed to reduce the porosity of the wheat bran, resulting in limited oxygen transfer (Sadhukhan et al., 1990). Low moisture content causes reduction in the solubility of nutrients of the substrates and low degree of swelling (Feniksova et al.,1960).

The first optimization experiment was performed to check the influence of different moisture content, which was varied by adding water to different concentrations $(40,50$ and $60 \%$ ). In solid state fermentation banana peel was used as a substrate for amylase production. In this experiment amylase activity and specific activity on banana peel were shown in Fig. 1 . The maximum amylase activity $(0.39942 \mathrm{U} / \mathrm{mL})$ was observed at $40 \%$ moisture and maximum specific activity $(1.8 \mathrm{U} / \mathrm{mL})$ was observed with $60 \%$ moisture content. Amylase activity and specific activity on corn are shown in Fig. 2. The maximum amylase activity and specific activity were respectively $0.70224 \mathrm{U} / \mathrm{mL}$ and $1.5 \mathrm{U} / \mathrm{mL}$ at $50 \%$ moisture content. Fig .3 shows the enzyme activity and specific activity on potato. The maximum amylase activity $(0.46788$ $\mathrm{U} / \mathrm{mL})$ and specific activity $(1.1 \mathrm{U} / \mathrm{mL})$ was observed at $50 \%$ moisture. On tapioca, the maximum amylase activity $(0.43512 \mathrm{U} / \mathrm{mL})$ and specific activity of $(4.58 \mathrm{U} / \mathrm{mL})$ was observed at $60 \%$ moisture (Fig. 4). Among these solid substrates tapioca yielded highest amylase activity $(4.43 \mathrm{U} / \mathrm{mL})$ at $60 \%$ moisture content.

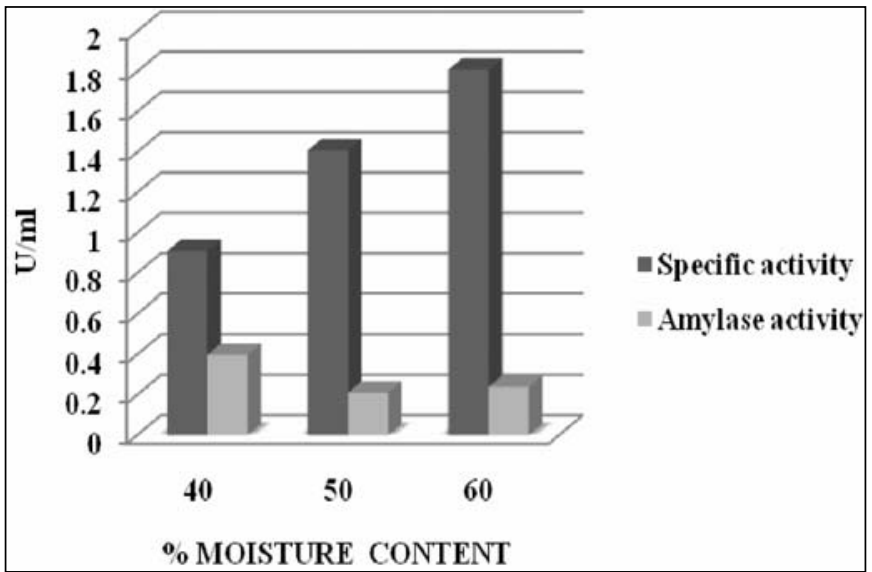

Fig. 1: Effect of banana peel on amylase activity and specific activity in different moisture contents

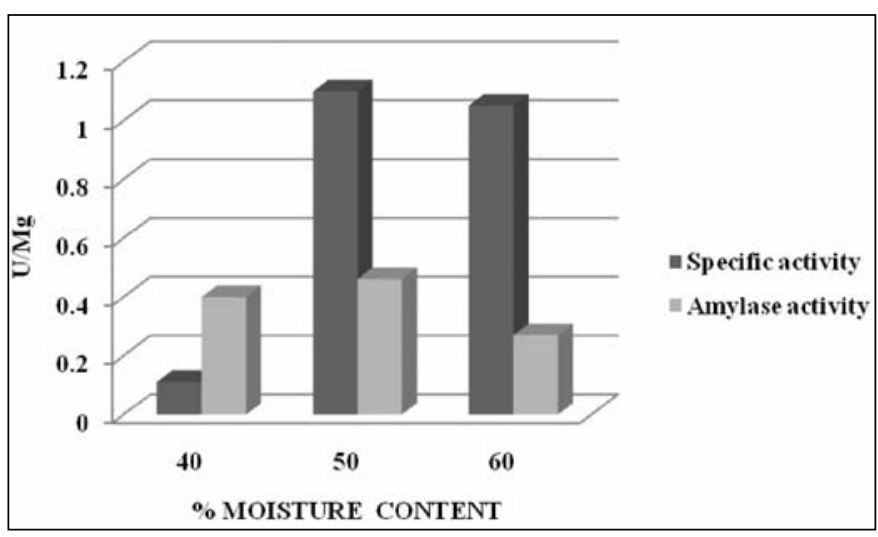

Fig. 2: Effect of corn on amylase activity and specific activity in different moisture contents

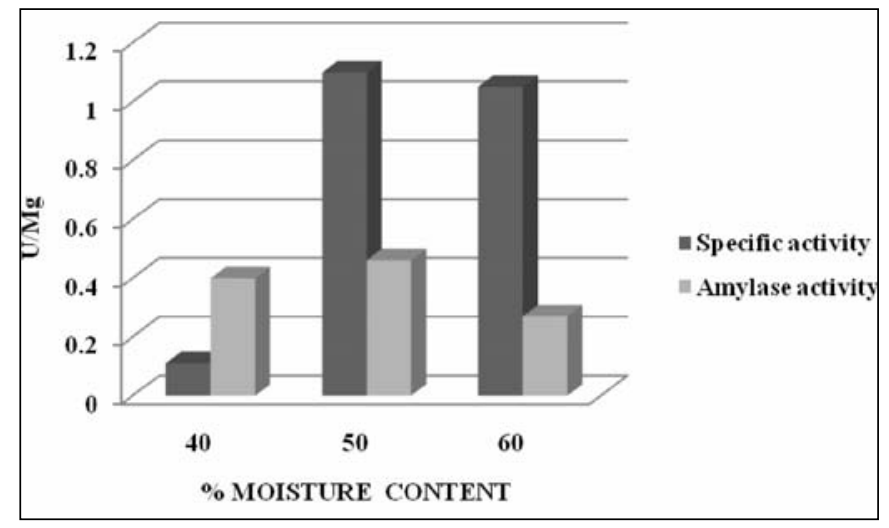

Fig. 3: Effect of potato on amylase activity and specific activity in different moisture contents 


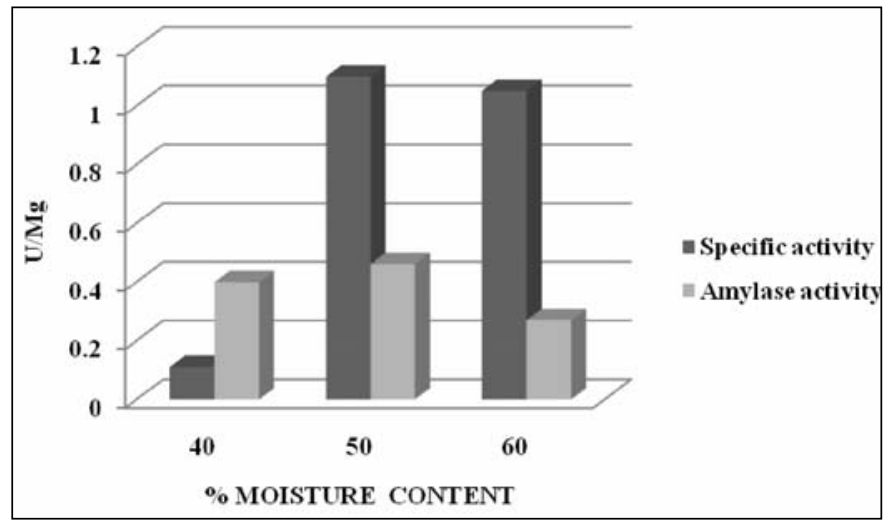

Fig. 4: Effect of tapioca on amylase activity and specific activity in different moisture contents

Irrespective of the substrates used, $60 \%$ moisture content was found to be optimal for amylase production. Tapioca, among the substrates has appreciable fibrous content in addition to starch, which avoided the compaction of the solid mass in due course of fermentation, there by promoting good

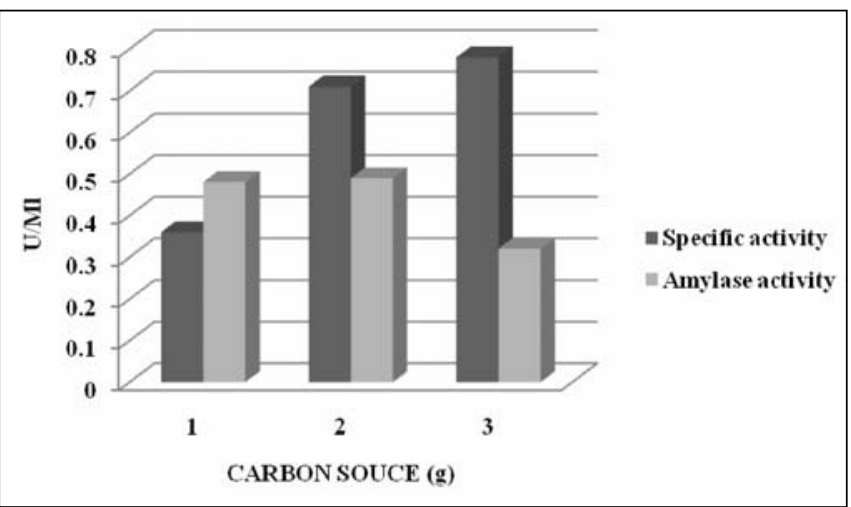

Fig. 5: Effect of carbon source on amylase activity and specific activity using Aspergillus niger

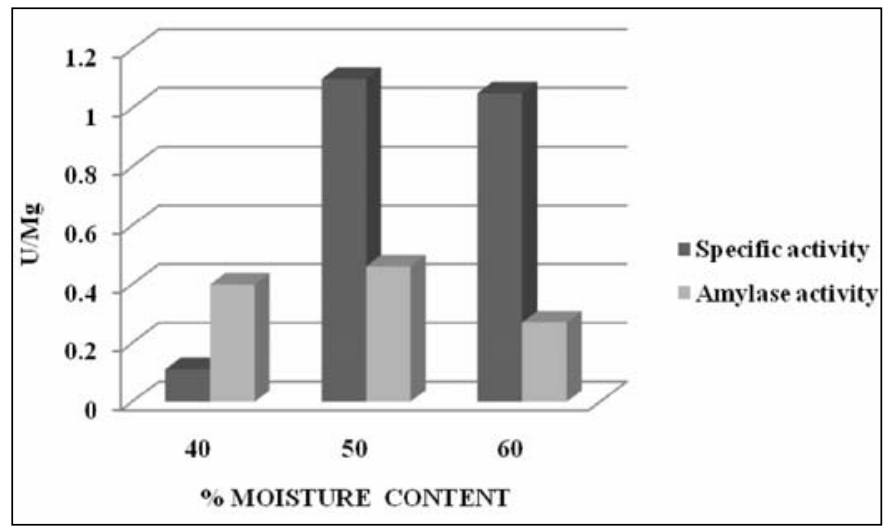

Fig. 6: Effect of nitrogen source on amylase activity and specific activity using Aspergillus niger aeration reaching the whole core of the substrate, in turn yielding more amylase. Whereas the other substrates like potato and corn could not promote better yield because of their compressible nature of solid packing, which reduced aeration. So from the above study, amylase production from tapioca was found to be the suitable solid substrate and the system can be scaled up for commercial production of amylase from solid substrate. Tapioca is traditionally used as a dessert or breakfast meal. As the development of technology become more sophisticated, tapioca starch is useful in textile industry, paper industry and for miscellaneous uses (Van damme et al., 2002). Tapioca contains almost $70-75 \%$ of starch. Therefore it is suitable for use as a substrate. Ramesh et al. (2001) reported that the biomass production by Clostridium thermosulfurogenes using barley and tapioca flour did not differ significantly when soluble starch was used as a carbon source.

In submerged liquid fermentation, amylase activity was influenced by varied carbon (starch) and nitrogen concentrations (Fig. 5 and Fig. 6). The maximum amylase activity $(0.49 \mathrm{U} / \mathrm{ml})$ and maximum specific activity $(0.78 \mathrm{U} / \mathrm{mL})$ was detected using $2 \mathrm{~g}$ and $3 \mathrm{~g}$ of starch concentration respectively. Highest enzyme activity $(1.23 \mathrm{U} / \mathrm{mL})$ and specific activity $(0.89 \mathrm{U} / \mathrm{mL})$ was observed in the highest concentration of nitrogen source used. From the above study it was seen that solid state fermentation yielded nearly 5 times more amylase activity as compared to submerged fermentation. Temperature and $\mathrm{pH}$ plays vital role in enzyme production. The fungal production highest amount of $\alpha$-amylase at temperature between 30 and $35{ }^{\circ} \mathrm{C}$ (Fig. 7), and at $\mathrm{pH}$ between 5 and 6 (Fig. 8). These results are in agreement to the other studies. Aspergillus niger UO-01 exhibited its best performance for enzyme production in the mesophilic range $\left(\mathrm{T}=30.2^{\circ} \mathrm{C}\right)$, as

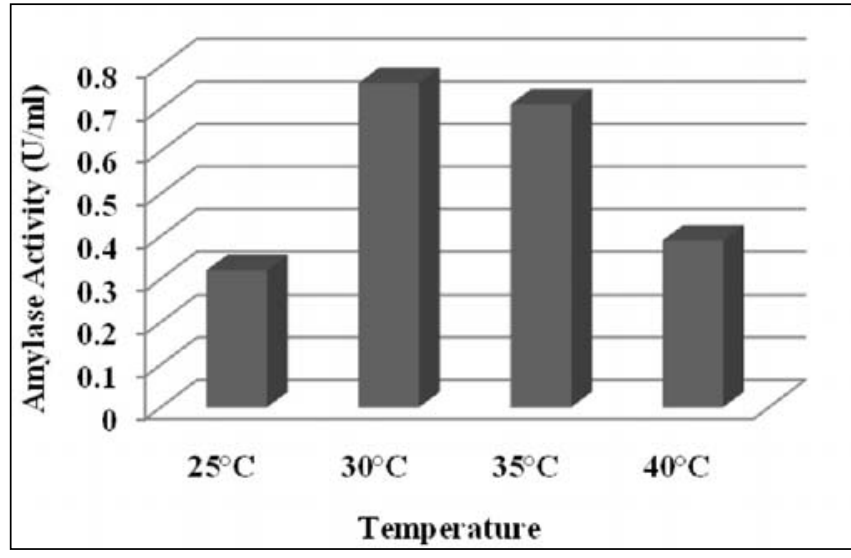

Fig. 7: Effect of temperature on amylase production 


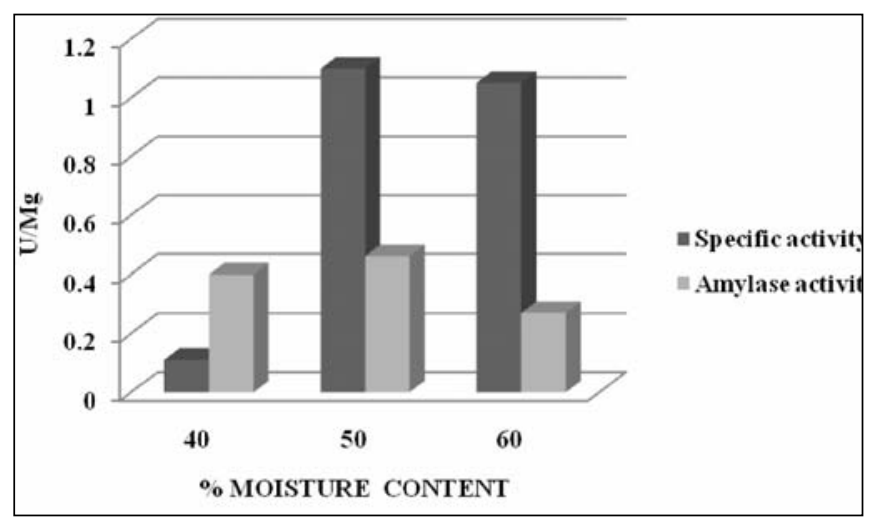

Fig. 8: Effect of pH on amylase production

it was reported before for $A$. niger LPB 28, which produce the highest amylase level at $30^{\circ} \mathrm{C}$ (Spier et al., 2006). Temperature values higher than $30^{\circ} \mathrm{C}$ may lead to enzymatic inactivation (Mazutti et al., 2006) or suppression of cell viability (Francis et al., 2002). In contrast, low temperature values may reduce the metabolism of the microorganism (Mazutti et al., 2006) and consequently, the enzyme synthesis. In this study, these results of present study suggest that Tapioca yielded highest amylase activity at 50\% moisture and it was also verified that $A$. niger has a preference for acidic $(\mathrm{pH} 5)$ and moderate temperature $\left(30^{\circ} \mathrm{C}\right)$ probably as a for growth and extracellular amylase production.

\section{Conclusion}

The purpose of this work is to study the optimized cultural conditions for the production of amylase by Aspergillus niger in solid state and submerged liquid fermentation. Four solid substrates Banana peel, Corn, Potato and tapioca with different moisture conditions were taken for solid state fermentation (SSF). From these substrates tapioca yielded 5 times higher than submerged liquid fermentation. So the commercial production of Amylase enzyme will be made feasible by successful scale up of these optimized parameters to industrial production in large scale fomenters.

\section{Acknowledgement}

Author thankful to Dr. S. Kannan, H.O.D, Department of Microbiology, Kurinji College of Arts and Sciences, for providing facilities.

\section{References}

Balkan B. and Ertan F. (2007). Production of $\alpha$-amylase from P. chrysogenum. Food Technol. Biotechnol. 45(4): 439-442.

Beckord L. D., Kneen E., and Lewis K. H. (1945). Bacterial amylases production on wheat bran. Ind. Eng. Chem. Ind. Ed. 37: 692-696.

Bhargav S., Panda B. P., Ali M. and Javed S. (2008). Solidstate fermentation: an overview. Chem. Biochem. Eng. Q. 22(1): 49-70.

Burhan A., Nisa U., Gokhan C., Omer C., Ashabil A. and Osman G. (2003). Enzymatic properties of a novel thermostable, thermophilic, alkaline and chelator resistant amylase from an alkaliphilic Bacillus sp. Isolate ANT-6. Process Biochem. 38(10): 1397-1403.

Ellaiah P., Adinarayana K., Bhavani Y., Padmaja P. and Srinivasulu B. (2002). Optimization of process parameters for glucoamylase production under solid state fermentation by a new isolated Aspergillus species. Process Biochem. 38(4): 615-620.

Feniksova R. V., Tikhomirova A. S. and Rakhleeva E. E. (1960). Conditions for forming amylase and proteinase in surface cultures of Bacillus subtilis. Microbiologia. 29(Sep-Oct): 745-748.

Francis F., Sabu A., Nampoothiri K. M., Ramachandran S., Ghosh S., Szakacs G. and Pandey A. (2003). Use of response surface methodology for optimizing process parameters for the production of $\alpha$-amylase by Aspergillus oryzae. Biochem. Eng. J. 15(2): 107-115.

Francis F., Sabu A., Nampoothiri K. M., Szakacs G. and Pandey A. (2002). Synthesis of $\alpha$-amylase by Aspergillus oryzae in solid-state fermentation. J. Basic. Microbiol. 42(5): 320-326.

Guerra N. P., Torrado A., Loipez C. and Pastrana L. (2003). Main characteristics and applications of solid substrate fermentation. Electron J. Environ. Agric. Food. Chem. 2(3): $343-350$

Hamilton L. M., Kelly C. T. and Fogarty W. M. (1999). Production and properties of the raw starch degrading 
alpha-amylase of Bacillus sp. Imd-435. Proc. Biochem. 35(1): 27-31.

Ibukun E. O. and Akindumila F. (1998). Extracellular amylase production by isolates of Bacilli micro organism cultured on different starchy food broths. Nig. J. Biochem. Mol. Biol. 13: 91-95.

John R. P., Nampoothiri K. M. and Pandey A. (2006). Solid state fermentation for L- lactic acid production from agro- wastes using Lactobacillus delbrueckii. Process Biochemistry. 41: 759-763.

Lowry O. H., Rosenbough H. I., Fair A. L. and Randall R. I. (1951). Protein measurement with the Folin phenol reagent. J. Biol. Chem. 193(1): 265-275.

Mazutti M., Bender J. P., Treichel H. and Di Luccio M., (2006). Optimization of inulinase production by solidstate fermentation using sugarcane bagasse as substrate. Enzyme. Microb. Technol. 39(1): 56-59

Miller G. L. (1959). Use of dinitrosalicylic acid reagent for determination of reducing sugar. Anal. Chem. 31(3): 426-428.

Okolo B. N., Ezeogu L. I. and Mba C. N. (1995). Production of raw starch digestive amylase by Aspergillus niger grown on native starch sources. J. Sci. Food Agric. 69(1): 109-115.

Ramesh B., Reddy P. R. M., Seenayya G. and Reddy G. (2001). Effect of various flours on the production of thermostable $\beta$-amylase and pullulanase by Clostridium thermosulfurogenes SV2. Biores. Technol. 76 (2): 169-171.

Rodriguez S. and Sanroman M. A. (2006). Application of solid-state fermentation to food industry-A review. $J$. Food Eng. 76 (3): 291-302.
Sadhukhan R. K., Manns S., Roy S. K. and Chakraborty S. L. (1990). Thermostable amyloytic amylase enzyme from a celluolytic fungus Myceliophthora thermophilla D14 ATCC 48104. Appl. Microbioal. Biotechnol. 33(6): 692-696.

Salas M., Rodriguez M., Guerra N. P. and Pe'rez R. (2006). Amylase production by Aspergillus niger in submerged cultivation on two wastes from food industries. J. Food Eng. 73 (1): 93-100.

Satyanarayana T. (1994). Production of bacterial extracellular enzymes by solid-state fermentation, In Pandey, A. (ed.) solid-state fermentation, Wiley Eastern Limited, New Delhi. 1994, pp. 122-129.

Spier M. R., Woiciechowski A. L., Vandenberghe L. P. S. and Zoclo C. R. (2006). Production and characterization of amylases by Aspergillus niger under solid state fermentation using agro industrials products. Int. J. Food Eng. 2(3): http:// www.bepress.com/ ijfe/ vol2/ iss3/ art6.

Uma Maheswar Rao J. L. and Satyanarayana, T. (2007). Improving production of hyperthermostable and high maltose-forming $\alpha$-amylase by an extreme thermophile Geobacillus thermoleovorans using response surface methodology and its applications. Bioresour. Technol. 98 (2): 345-352.

Van damme Th. F., Lenourry A., Charrueau C. and Chaumeil J. C. (2002). The use of polysaccharides to target drugs to the colon. Carbohydrate polymers. 48(3): 219-231.

Received: March 24, 2011;

Accepted : August 23, 2011 